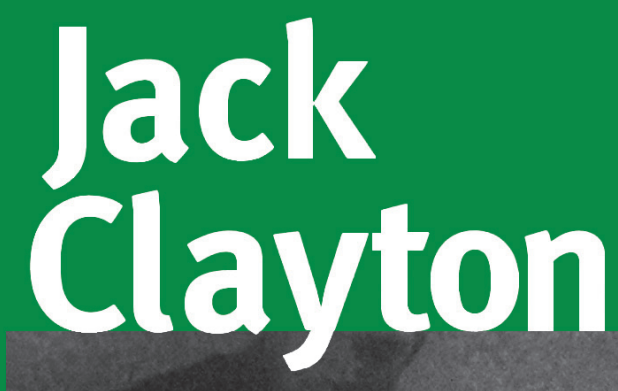

\title{
BRITISH
}

FILM

MAKERS

NEIL SINYARD

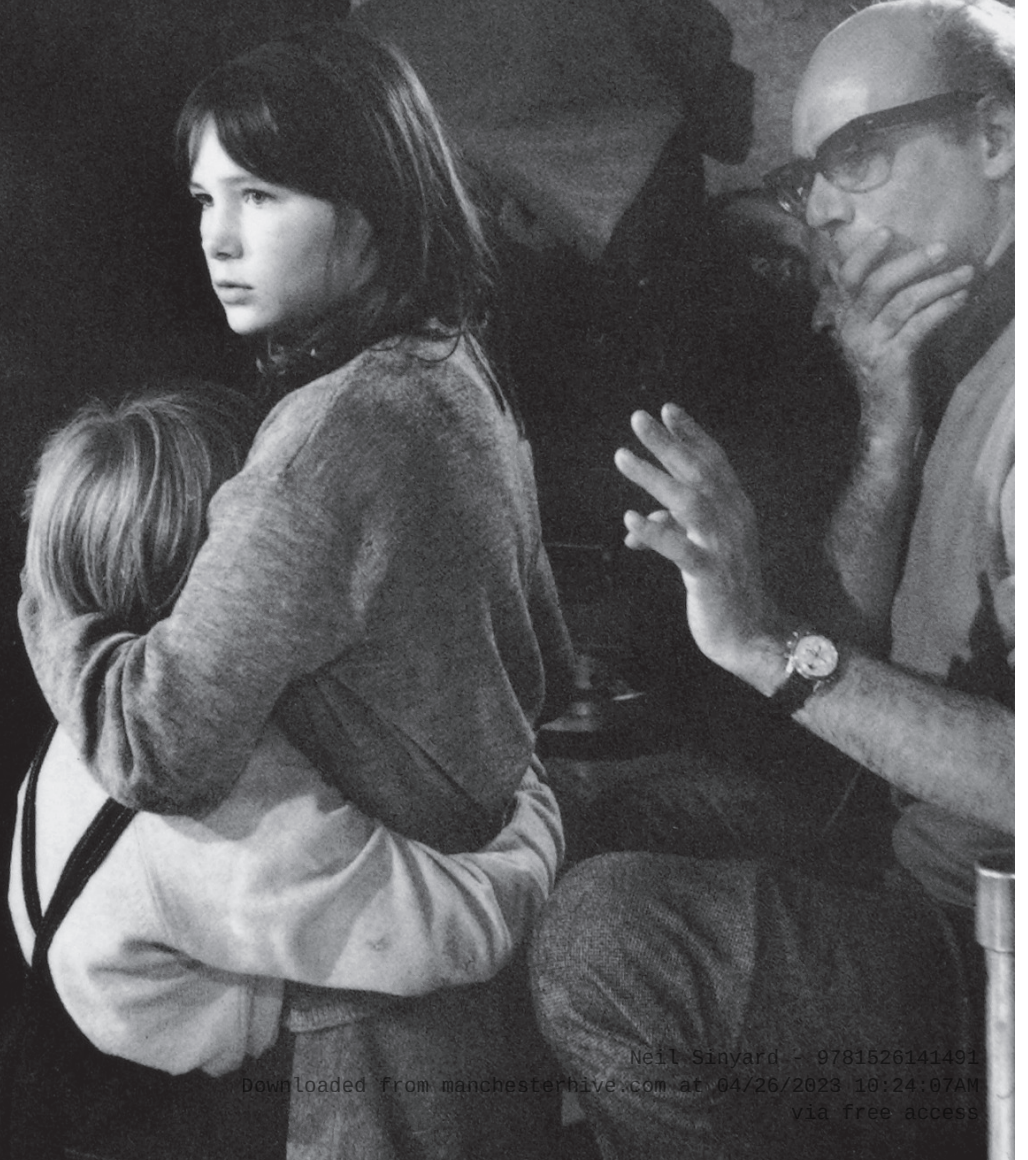




\section{Jack Clayton}

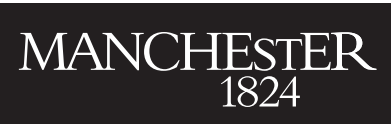

Manchester University Press 
Brian McFarlane, Neil Sinyard series editors

BRITISH

Allen Eyles, Philip French, Sue Harper, FILM

Tim Pulleine, JefFrey Richards, Tom Ryall

MAKERS

series advisers

already published

Lance Comfort BRIAN MCFARLANE

forthcoming titles

Terence Fisher PETER HUTCHINGS

Pat Jackson CHARLES BARR

Launder and Gilliat BRUCE BABINGTON

J. Lee Thompson STEVE CHIBNALL 


\section{BRITISH \\ Jack Clayton \\ MAKERS}

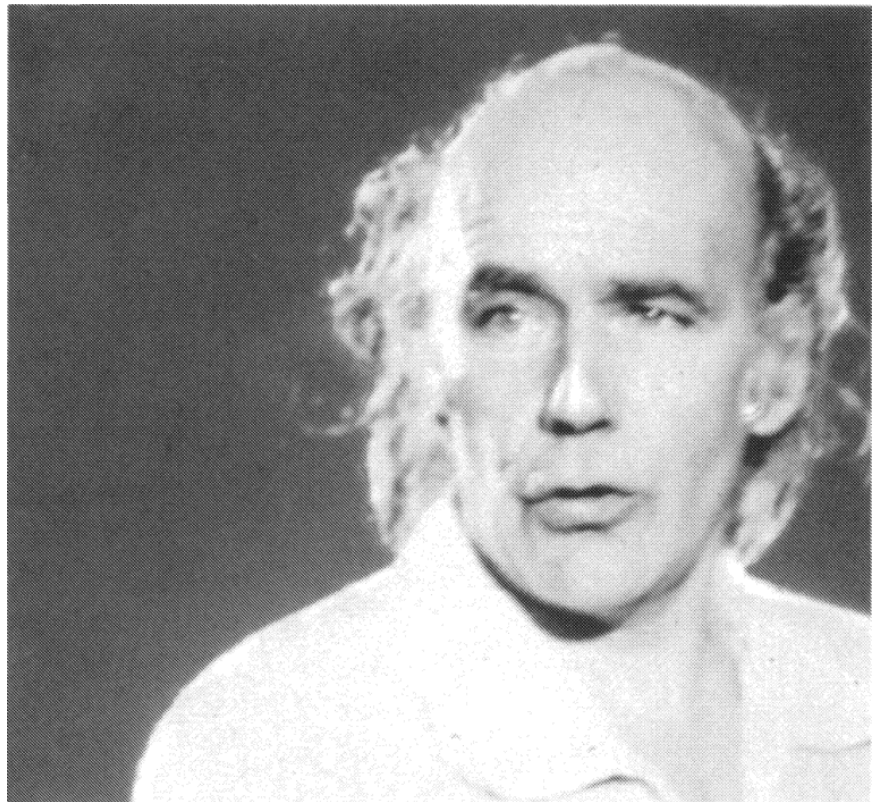

NeIL SinYARD

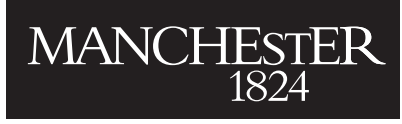

Manchester University Press 


\section{Copyright (c) Neil Sinyard 2000}

The right of Neil Sinyard to be identified as the author of this work has been asserted by him in accordance with the Copyright, Designs and Patents Act 1988.

Published by Manchester University Press

Altrincham Street, Manchester Ml 7JA, UK

www.manchesteruniversitypress.co.uk

British Library Cataloguing-in-Publication Data is available Library of Congress Cataloging-in-Publication Data is available

ISBN 9780719055058 paperback

First published by Manchester University Press 2000

The publisher has no responsibility for the persistence or accuracy of URLs for any external or third-party internet websites referred to in this book, and does not guarantee that any content on such websites is, or will remain, accurate or appropriate. 